(2) Open Access Full Text Article

\title{
Survival Time to Modern Contraceptive Uses from the Resumption of Sexual Intercourse Among Postpartum Women in Ethiopia
}

This article was published in the following Dove Press journal: International Journal of Women's Health

\author{
Mohammed Ahmed (1D' \\ Abdu Seid (D) ${ }^{2}$ \\ 'Department of Public Health, College of \\ Health Science, Woldia University, \\ Woldia, Ethiopia; ${ }^{2}$ Department of \\ Midwifery, College of Health Science, \\ Woldia University, Woldia, Ethiopia
}

Background: The timing of contraceptive use is important for a woman who intends to avoid pregnancy during the postpartum period and it has key implications for reproductive health outcomes. Therefore, this study aimed to determine the time it takes to start modern contraceptive uses from the resumption of sexual intercourse among postpartum women in Ethiopia and to identify its predictors.

Methods: A cross-sectional study using the 2016 Ethiopia Demographic and Health Survey (EDHS) was applied. The data were analyzed with SPSS version 20. Kaplan-Meier estimates were performed to explain time-to- modern contraceptive use. Cox-proportional hazard regression analysis was conducted to identify predictors. The adjusted hazard ratio (AHR) with a $95 \%$ confidence interval was considered to declare a statistically significant association.

Results: The total weighted sample comprised 1178 women. The median survival time to modern contraceptive use after birth was 4 months. In this study, the risk of modern contraceptive use was 1.29 times (AHR: 1.29; 95\% CI: 1.04-1.61) higher among urban resident, 1.26 times (AHR: 1.26; 95\% CI: 1.09-1.47) higher among women's attended primary education and 1.19 times (AHR: 1.19; 95\% CI: 1.02-1.38) higher among women's accessed media. But, the risk of modern contraceptive use was lower among breastfeeding women by $17 \%$ (AHR: 0.83 ; 95\% CI: $0.74-0.95$ ).

Conclusion: The median survival timing of modern contraceptive use from the resumption of sexual intercourse was four months. Women residing in urban area, who attended primary education and accessed to media shorten the time to use contraceptives after birth, whereas women breastfed their infant lengthen the time to use a modern contraceptive. Therefore, the health-care provider should enhance modern contraceptive use through health education and promotion to curb down the four months lag period identified by considering the spotted factors.

Keywords: survival time, modern contraceptive, resumption, postpartum woman, Ethiopia

\section{Background}

The crucial time to use modern contraceptive methods to prevent unwanted pregnancy is during the first year of the postpartum period. ${ }^{1}$ According to the World Health Organization (WHO) medical eligibility criteria for contraceptive use, women should be offered contraceptives within the first month of postpartum. ${ }^{2}$

Despite more than $90 \%$ of women during the first year of the postpartum period want to either delay or avoid future pregnancies in the globe, sexual activity is resumed without using any contraceptive method. ${ }^{3}$ In sub-Saharan Africa, nearly
Correspondence: Mohammed Ahmed Email mohaasrar12@gmail.com
International Journal of Women's Health 2020:12 64I-647 
one-third of postpartum women are exposed to the risk of pregnancy by having sex without using the contraceptive method within 2 years after childbirth. ${ }^{4}$

Abstinence from sexual intercourse and the resumption of sexual activity after childbirth varies from culture to culture. $^{5}$ In Nigeria, of the women who had resumed vaginal intercourse during the puerperium, only $12 \%$ of them were using contraception. ${ }^{6}$ While in Ethiopia, a high number of postpartum women resumed sexual intercourse despite one in ten women resumed without contraceptive use. $^{7}$

A sexually active woman after delivery not using an effective contraceptive method increase her vulnerability to unintended pregnancy in the month before her first menstruation, which results in poor maternal and child health outcomes. ${ }^{8}$ Family planning use during the first year postpartum has the potential to reduce unintended pregnancies. ${ }^{8}$ A study has shown that children, who have a short birth interval, especially if the interval is less than 24 months, are at increased risk of morbidity and mortality that can easily be prevented by using modern contraceptive methods at the right time after delivery. ${ }^{9}$

Studies were done in Nairobi, and Uganda showed that the median survival time to first use of a modern contraceptive method from the resumption of sexual intercourse during the postpartum period indicates seventh and nineteen months, respectively. ${ }^{10,11}$
Various studies have identified factors which affect timing of modern contraceptive uptake during postpartum period such as age of the women 35 and above, ${ }^{12}$ higher educational status, ${ }^{13-17}$ residence, ${ }^{17-19}$ wealth index, ${ }^{20-22}$ marital status, ${ }^{12,14,17}$ religion and source of information. ${ }^{20,23,24}$ Besides, the timing of modern contraceptive uptake was significantly longer among women with no formal education, had delivered at home/traditional birth attendant, and had 1-3 antenatal care visits. $^{11}$

The timing of contraceptive use from the resumption of sexual intercourse is important for a woman who intends to avoid pregnancy during the postpartum period and it has key implications for reproductive health outcomes. ${ }^{10}$ However, the timing for the initiation of modern contraception from the resumption of sexual intercourse following birth, in which to date there is scarce evidence in Ethiopia. Therefore, this study was designed to determine the time it takes postpartum women in Ethiopia to start using modern contraceptives from the resumption of sexual intercourse and to identify factors predicting the uptake.

\section{Methods \\ Data Source}

The current study uses secondary data from the 2016 Ethiopia Demographic and Health Survey (EDHS). A detailed description of the study design and

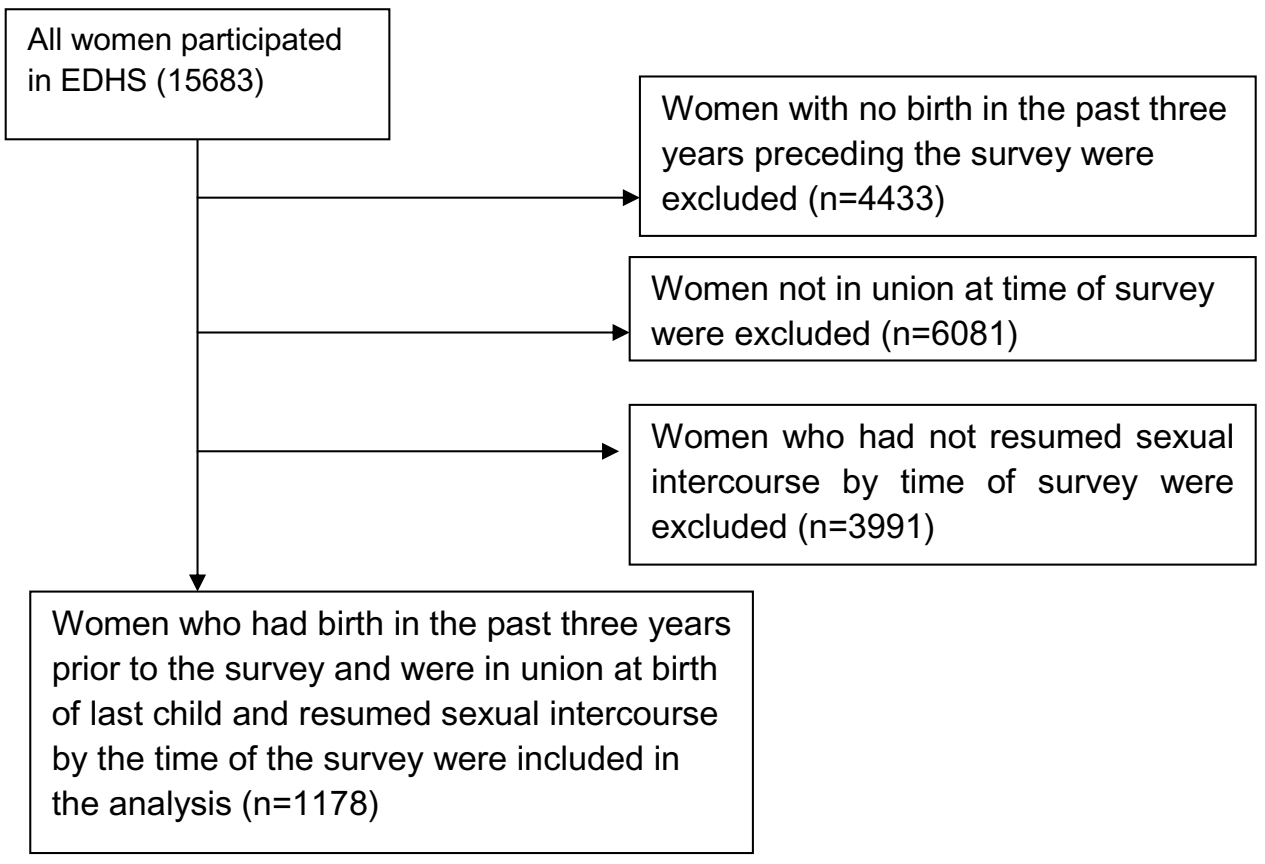

Figure I Flowchart showing how the weighted sample used in the study was derived. 
methodology of 2016 is found elsewhere. ${ }^{25}$ A nationally representative sample was obtained based on a two-stage cluster sampling. The first and second stages involved the selection of the clusters and households in each cluster, respectively. Further, stratification by rural-urban areas was taken into account. This study was based on data from the Woman's questionnaire, which was administered to all women aged 15-49 in the selected households.

\section{Selection Criteria}

The sample utilized in this study excluded (i) women who were not in a marital union ( $\mathrm{n}=6801$ ); (ii) women with no births in the past three years preceding the survey $(n=4433)$; and (iii) women who had not resumed sexual intercourse by the time of the survey $(n=3991)$. The analytic sample for the current study consisted of married women with a birth in the past three years preceding the survey who had resumed sexual intercourse $(n=1178)$ because they have a higher chance of utilized contraceptive due to joint decisionmaking power from their husbands (Figure 1).

\section{Study Variables}

Time to modern contraceptive uses (pill, intrauterine device, injection, diaphragm, condom, sterilization, and implant) from the resumption of sexual intercourse after birth was the outcome of interest. It was estimated in months, by the period from the resumption of sexual intercourse after birth to the time when a woman used modern contraception.

The independent variables were selected based on a literature review which deemed to be the factors associated with modern contraceptive use and includes age, education level of the women, wealth index, residence, working status (occupation), parity, sex of the child, type of birth, breastfeeding, mode of delivery, place of delivery, exposure to media.

\section{Data Processing and Analysis}

The data were analyzed using SPSS version 20. Frequencies and weighted percentage of study variables were calculated. Kaplan-Meier survival estimate was used to explain the timing of modern contraceptive use from the resumption of sexual intercourse after birth. Multivariate Cox-proportional hazard regression analysis was performed to identify the factors associated with time to modern contraceptive use from the resumption of sexual intercourse after birth. Adjusted hazard ratios (AHR) with 95\% Confidence interval (CI) were used to declare a statistically significant association. The model
Table I Profile of Respondents by Frequency and Weighted Percentage $(n=|| 78)$

\begin{tabular}{|c|c|c|c|}
\hline Variables & Category & Frequency & $\begin{array}{l}\text { Weighted } \\
\text { Percent (Wt. \%) }\end{array}$ \\
\hline $\begin{array}{l}\text { Age of } \\
\text { respondents } \\
\text { (years) }\end{array}$ & $\begin{array}{l}15-19 \\
20-29 \\
30-39 \\
40-49\end{array}$ & $\begin{array}{l}61 \\
703 \\
354 \\
60\end{array}$ & $\begin{array}{l}5.2 \\
59.7 \\
30.1 \\
5.1\end{array}$ \\
\hline Residence & $\begin{array}{l}\text { Urban } \\
\text { Rural }\end{array}$ & $\begin{array}{l}435 \\
743\end{array}$ & $\begin{array}{l}36.9 \\
63.1\end{array}$ \\
\hline $\begin{array}{l}\text { Educational } \\
\text { status }\end{array}$ & $\begin{array}{l}\text { No } \\
\text { Education } \\
\text { Primary } \\
\text { Secondary } \\
\text { Higher }\end{array}$ & $\begin{array}{l}441 \\
463 \\
161 \\
113\end{array}$ & \begin{tabular}{l|}
37.4 \\
\\
39.3 \\
13.7 \\
9.6
\end{tabular} \\
\hline Wealth index & $\begin{array}{l}\text { Poorest } \\
\text { Poorer } \\
\text { Middle } \\
\text { Richer } \\
\text { Richest }\end{array}$ & $\begin{array}{l}136 \\
174 \\
180 \\
200 \\
488\end{array}$ & $\begin{array}{l}11.5 \\
14.8 \\
15.3 \\
17.0 \\
41.4\end{array}$ \\
\hline Occupation & $\begin{array}{l}\text { Un } \\
\text { Employed } \\
\text { Agricultural } \\
\text { Non- } \\
\text { agricultural }\end{array}$ & $\begin{array}{l}606 \\
225 \\
347\end{array}$ & $\begin{array}{l}51.4 \\
19.1 \\
29.5\end{array}$ \\
\hline Place of delivery & $\begin{array}{l}\text { Home } \\
\text { Health } \\
\text { Institution }\end{array}$ & $\begin{array}{l}425 \\
753\end{array}$ & $\begin{array}{l}36.1 \\
63.9\end{array}$ \\
\hline Mode of delivery & $\begin{array}{l}\text { Vaginal } \\
\text { Cesarean } \\
\text { Section }\end{array}$ & $\begin{array}{l}1096 \\
82\end{array}$ & $\begin{array}{l}93.0 \\
7.0\end{array}$ \\
\hline Type of birth & $\begin{array}{l}\text { Single } \\
\text { Multiple }\end{array}$ & $\begin{array}{l}1161 \\
17\end{array}$ & $\begin{array}{l}98.6 \\
1.4\end{array}$ \\
\hline Sex of the child & $\begin{array}{l}\text { Male } \\
\text { Female }\end{array}$ & $\begin{array}{l}634 \\
544\end{array}$ & $\begin{array}{l}53.8 \\
46.2\end{array}$ \\
\hline Parity & $\begin{array}{l}\text { One } \\
2-4 \\
>4\end{array}$ & $\begin{array}{l}357 \\
571 \\
250\end{array}$ & $\begin{array}{l}30.3 \\
48.5 \\
21.2\end{array}$ \\
\hline $\begin{array}{l}\text { Currently breast } \\
\text { feeding }\end{array}$ & $\begin{array}{l}\text { No } \\
\text { Yes }\end{array}$ & $\begin{array}{l}257 \\
921\end{array}$ & $\begin{array}{l}21.8 \\
78.2\end{array}$ \\
\hline Access to media & $\begin{array}{l}\text { No } \\
\text { Yes }\end{array}$ & $\begin{array}{l}525 \\
653\end{array}$ & $\begin{array}{l}44.6 \\
55.4\end{array}$ \\
\hline
\end{tabular}

fitness was assessed using link specification test which shows the model was fitted by having hat-statistic = $0.772, p=0.00$; hat-square $=0.034, p=0.612$. As recommended, sampling weights that accounted for complex survey design were incorporated in all analyses. 


\section{Ethics Approval and Consent to Participate}

Ethical clearance for the study is not required since it is secondary data analysis from EDHS 2016 database. The researchers have received the survey data from USAID-DHS program and then the researchers of this study have maintained the confidentiality of the data. The consent was obtained from the study participants before study commencement.

\section{Results}

\section{Participant's Characteristics}

A total of 1178 samples of women within the EDHS 2016 were included and analyzed. About, $63.1 \%$ of respondents were rural residents, and $59.7 \%$ of participants were found in the age between 20 and 29 years. Out of these samples, $39.3 \%$ of the respondent attended primary education. Only, $63.9 \%$ of women delivered their last child in a health institution and $55.4 \%$ had access to media (Table 1).

\section{Time to Modern Contraceptive Uses from the Resumption of Sexual Intercourse Among Postpartum Women in Ethiopia}

From 1178 women assessed in the study, 1155 (98.05\%) women used a modern contraceptive method by the date of the interview. The estimated proportion of modern contraceptive users at the time of resumption of sexual intercourse was $134(11.4 \%)$. Likewise, the proportion of women using contraception at the first, second, and third months after the resumption of sexual intercourse following birth were 122 (11.7\%), 129 (14.1\%), and 128 $(16.3 \%)$, respectively. The median survival time to modern contraceptive use from the resumption of sexual intercourse following birth was about 4 months (Table 2).

\section{Predictors of Survival Time to Modern Contraceptive Uses from the Resumption of Sexual Intercourse Among Postpartum Women in Ethiopia}

All the variables were entered into multivariate Coxproportional hazard regression analysis using the enter method. After adjusting for potential confounders by the regression, residents, educational status of women, breastfeeding, and access to media were predicting the timing of modern contraceptive use from the resumption of sexual intercourse among post-partum women in Ethiopia.

In this study, the risk of modern contraceptive use from the resumption of sexual intercourse among postpartum women were 1.29 (adjusted hazard ratio (AHR): 1.29; 95\% CI: 1.04-1.61) times higher among urban resident compared to rural, 1.26 times (AHR: 1.26; 95\% CI: 1.09 $-1.47)$ higher among women's attended primary education compared to non educated one, and 1.19 times (AHR: 1.19; 95\% CI: 1.02-1.38) higher among women's accessed media compared to their counterparts.

Table 2 Illustration of Kaplan-Meier Survival Estimate on Time to Modern Contraceptives Uses from the Resumption of Sexual Intercourse Among Postpartum Women in Ethiopia $(n=1178)$

\begin{tabular}{|l|l|l|l|l|l|l|}
\hline $\begin{array}{l}\text { Time (in } \\
\text { Months) }\end{array}$ & $\begin{array}{l}\text { Number } \\
\text { at Risk }\end{array}$ & $\begin{array}{l}\text { Modern Contraceptive } \\
\text { User at Each Month }\end{array}$ & Censored & $\begin{array}{l}\text { Estimated Proportion of } \\
\text { Modern Contraceptive } \\
\text { User }\end{array}$ & $\begin{array}{l}\text { Estimated } \\
\text { Proportion of } \\
\text { Surviving }\end{array}$ & $\begin{array}{l}\text { Estimated } \\
\text { Cumulative } \\
\text { Survival }\end{array}$ \\
\hline 0 & 1178 & 134 & 3 & 0.114 & 0.886 & 0.886 \\
1 & 1041 & 122 & 2 & 0.117 & 0.883 & 0.782 \\
2 & 917 & 129 & 2 & 0.141 & 0.859 & 0.672 \\
3 & 786 & 128 & 1 & 0.163 & 0.837 & 0.522 \\
4 & 657 & 117 & 1 & 0.178 & 0.772 & 0.463 \\
5 & 539 & 123 & 2 & 0.228 & 0.780 & 0.357 \\
6 & 414 & 91 & 3 & 0.220 & 0.728 & 0.279 \\
7 & 320 & 87 & 3 & 0.272 & 0.696 & 0.203 \\
8 & 230 & 70 & 2 & 0.304 & 0.551 & 0.141 \\
9 & 158 & 71 & 2 & 0.449 & 0.318 & 0.078 \\
10 & 85 & 58 & 0 & 0.682 & 0.111 & 0.025 \\
11 & 27 & 24 & 2 & 0.889 & 0.000 & 0.003 \\
12 & 1 & 1 & 0 & 1.000 & 0.000 \\
\hline
\end{tabular}


Besides, the risk of modern contraceptive use from the resumption of sexual intercourse after birth was lower by 17\% (AHR: 0.83; 95\% CI: 0.74-0.95) among breastfeeding women compared to nonbreastfeeding ones (Table 3).

\section{Discussion}

The timing of modern contraceptive use during the postpartum period is indispensable for a woman who intends to avoid pregnancy during the postpartum period. This study aimed to determine the time to modern contraceptives use from the resumption of sexual intercourse among postpartum women in Ethiopia and identified its predictors.

The median survival timing of modern contraceptive use from the resumption of sexual intercourse in this study was 4 months. This finding was contrary to previous studies done in Nairobi ${ }^{10}$ and Uganda ${ }^{11}$ which reported median time to contraceptive use was 7 and 19 months, respectively. This may be due to socio-cultural differences between countries and sample variation.

Moreover, the median survival time to modern contraceptive use in this study was longer compared to a study done in Uganda which reported a median time of three months. ${ }^{26}$ The possible explanation for the difference could be explained by the difference in population characteristics. The study in Uganda was a clinical trial using HIV negative and HIV positive population while our study included generally all women of the reproductive age population.

Predictors of time to modern contraceptive use include residence, educational status of women, breastfeeding status, and access to media.

Regarding residence, the risk of modern contraceptive use was higher among urban residents compared to rural residents. This finding was supported by a study conducted in Nigeria. ${ }^{27}$ In the same vein, the risk of modern contraceptive use was higher among women who had media access compared to their counterparts. This may be due to the ability of a woman to get information regarding modern contraceptives that could be increased as a result of media exposure.

Likewise, the risk of modern contraceptive use was higher among women's attended primary education compared to non-educated ones. The finding is consistent with studies done in a different countries. ${ }^{11,13,28,29}$ A study done in
Table 3 Multivariate Cox-Regression Analysis Showed Predictors of Time to Modern Contraceptives Use from the Resumption of Sexual Intercourse Among Postpartum Women in Ethiopia $(n=1178)$

\begin{tabular}{|c|c|c|c|}
\hline Variables & Category & $\begin{array}{l}\text { Unadjusted } \\
\text { Hazard Ratio (95\% } \\
\mathrm{Cl)}\end{array}$ & $\begin{array}{l}\text { Adjusted } \\
\text { Hazard Ratio } \\
(95 \% \mathrm{Cl})\end{array}$ \\
\hline $\begin{array}{l}\text { Age of } \\
\text { respondents } \\
\text { (years) }\end{array}$ & $\begin{array}{l}15-19 \\
20-29 \\
30-39 \\
40-49\end{array}$ & $\begin{array}{l}\text { Ref } \\
0.73(0.51-1.05) \\
0.74(0.56-0.96) \\
0.75(0.56-0.98)\end{array}$ & $\begin{array}{l}\text { Ref } \\
0.93(0.69-1.23) \\
1.003(0.72-1.38) \\
0.93(0.60-1.43)\end{array}$ \\
\hline Residence & $\begin{array}{l}\text { Urban } \\
\text { Rural }\end{array}$ & $\begin{array}{l}1.02(0.90-1.15) \\
\text { Ref }\end{array}$ & $\begin{array}{l}1.29(1.04-1.61)^{* *} \\
\text { Ref }\end{array}$ \\
\hline $\begin{array}{l}\text { Educational } \\
\text { status }\end{array}$ & $\begin{array}{l}\text { No } \\
\text { Education } \\
\text { Primary } \\
\text { Secondary } \\
\text { Higher }\end{array}$ & $\begin{array}{l}\text { Ref } \\
1.93(0.82-2.10) \\
0.95(0.78-1.13) \\
0.89(0.72-1.10\end{array}$ & $\begin{array}{l}\text { Ref } \\
1.26(1.09-1.47)^{* *} \\
1.15(0.92-1.45) \\
1.22(0.91-1.61)\end{array}$ \\
\hline Wealth index & $\begin{array}{l}\text { Poorest } \\
\text { Poorer } \\
\text { Middle } \\
\text { Richer } \\
\text { Richest }\end{array}$ & $\begin{array}{l}\text { Ref } \\
0.95(0.76-1.19) \\
0.91(0.73-1.14) \\
1.08(0.87-1.33) \\
0.94(0.77-1.13)\end{array}$ & $\begin{array}{l}\text { Ref } \\
0.75(0.60-1.35) \\
1.25(0.59-1.54) \\
0.77(0.55-1.21) \\
0.92(0.70-1.20)\end{array}$ \\
\hline Occupation & $\begin{array}{l}\text { Un } \\
\text { Employed } \\
\text { Agricultural } \\
\text { Non- } \\
\text { agricultural }\end{array}$ & $\begin{array}{l}\text { Ref } \\
1.13(0.96-1.31) \\
1.01(0.87-1.14)\end{array}$ & $\begin{array}{l}\text { Ref } \\
1.13(0.95-1.32) \\
0.86(0.74-1.29)\end{array}$ \\
\hline $\begin{array}{l}\text { Place of } \\
\text { delivery }\end{array}$ & $\begin{array}{l}\text { Home } \\
\text { Health } \\
\text { Institution }\end{array}$ & $\begin{array}{l}\text { Ref } \\
1.04(0.92-1.16)\end{array}$ & $\begin{array}{l}\text { Ref } \\
1.13(0.97-1.31)\end{array}$ \\
\hline $\begin{array}{l}\text { Mode of } \\
\text { delivery }\end{array}$ & $\begin{array}{l}\text { Vaginal } \\
\text { Cesarean } \\
\text { Section }\end{array}$ & $\begin{array}{l}\text { Ref } \\
0.94(0.74-1.19)\end{array}$ & $\begin{array}{l}\text { Ref } \\
\text { I.15(0.89-1.47) }\end{array}$ \\
\hline Type of birth & $\begin{array}{l}\text { Single } \\
\text { Multiple }\end{array}$ & $\begin{array}{l}\text { Ref } \\
\text { I.48(0.92-2.38) }\end{array}$ & $\begin{array}{l}\text { Ref } \\
1.06(0.65-1.74)\end{array}$ \\
\hline $\begin{array}{l}\text { Sex of the } \\
\text { child }\end{array}$ & $\begin{array}{l}\text { Male } \\
\text { Female }\end{array}$ & $\begin{array}{l}\text { Ref } \\
1.05(0.94-1.18)\end{array}$ & $\begin{array}{l}\text { Ref } \\
0.91(0.80-1.02)\end{array}$ \\
\hline Parity & $\begin{array}{l}\text { One } \\
2-4 \\
>4\end{array}$ & $\begin{array}{l}0.90(0.76-1.06) \\
0.87(0.75-1.02) \\
\text { Ref }\end{array}$ & $\begin{array}{l}1.01(0.86-1.17) \\
0.97(0.76-1.25) \\
\text { Ref }\end{array}$ \\
\hline $\begin{array}{l}\text { Currently } \\
\text { breast feeding }\end{array}$ & $\begin{array}{l}\text { No } \\
\text { Yes }\end{array}$ & $\begin{array}{l}\text { Ref } \\
0.74(0.91-1.20)\end{array}$ & $\begin{array}{l}\text { Ref } \\
0.83(0.74-0.95)^{* *}\end{array}$ \\
\hline $\begin{array}{l}\text { Access to } \\
\text { media }\end{array}$ & $\begin{array}{l}\text { No } \\
\text { Yes }\end{array}$ & $\begin{array}{l}\text { Ref } \\
1.25(0.85-1.60)\end{array}$ & $\begin{array}{l}\text { Ref } \\
1.19(1.02-1.38)^{* *}\end{array}$ \\
\hline
\end{tabular}

Notes: Double asterisk $(* *)$ shows a statistically significant association. Model fitness: Hat-statistic $=0.772, p=0.00$; Hat-square $=0.034, p=0.612$ Abbreviation: Ref, reference category. 
six Sub-Saharan African countries revealed that post primary education was associated with increased odds of modern contraceptive use, but the study also arrives at the same conclusion among women with primary education. ${ }^{15}$ This evidence implies that the minimum level of education associated with contraceptive use may vary across countries and regions.

Regarding breastfeeding, the risk of modern contraceptive use was lower among women who had breastfed their child than their counterparts. This finding is contrary to previous studies ${ }^{11,30}$ that reported no significant difference between breastfeeding and nonbreastfeeding women. The possible reason for the observed difference could be due to variation in population characteristics. But, finding is consistent with previous studies ${ }^{31,32}$ which showed that breastfeeding lengthen postpartum amenorrhea and eventually delaying initiation of modern contraception as they perceive to be protected.

\section{Conclusion}

The median survival timing of modern contraceptive use from the resumption of sexual intercourse in this study was four months. Residence in an urban area, women attended primary education and accessed to media shorten the time to use contraceptives after birth, whereas women breastfed their infant lengthen the time to use a modern contraceptive. Health policymakers and family planning programmers as well as community health workers and health-care providers should give a great emphasis by focusing in a rural area, among women did not attend formal education, those did not access to media, and breastfeeding women through health education and promotion to curb down the 4-month lag period.

\section{Abbreviations}

AHR, adjusted hazard ratio; CI, confidence interval; EDHS, Ethiopia Demographic and Health Survey; HIV, human immune virus; SPSS, Statistical Package for Social Science; WHO, World Health Organization.

\section{Data Sharing Statement}

For this analysis, we used the USAID-DHS program 2016 Ethiopian demographic and health survey data set. To request the same or different data for another purpose, a new research project request should be submitted to the DHS program here: https://dhsprogram.com/data/AccessInstructions.cfm. The DHS Program will normally review all data requests within 24-48 hours (during working days) and provide notification if access has been granted, or additional project information is needed before access can be granted. After receiving permission, the researcher can $\log$ in and select the specific data in the format they prefer.

\section{Acknowledgments}

We are grateful to the USAID-DHS program for providing access to 2016 Ethiopia Demographic and Health Survey.

\section{Author Contributions}

All authors made a significant contribution to the work reported, whether that is in the conception, study design, execution, acquisition of data, analysis, and interpretation, or in all these areas; took part in drafting, revising or critically reviewing the article; gave final approval of the version to be published; have agreed on the journal to which the article has been submitted; and agree to be accountable for all aspects of the work.

\section{Funding}

There is no funding to report.

\section{Disclosure}

We confirm that this research is our original paper and that there is no conflict of interest in this work.

\section{References}

1. WHO, USAID. Africa's health in 2010. Repositioning family planning: guidelines for advocacy action. 2011.

2. WHO. Medical Eligibility Criteria for Contraceptive Use. World Health Organization; 2015.

3. World Health Organization. Partner release programming strategies for postpartum family planning global health. Sci Pract. 2014;2(1):4-9.

4. Clements S, Madise N, Who is being served least by family planning providers? A study of modern contraceptive use in Ghana, Tanzania And Zimbabwe. Afr $J$ Reprod Health. 2004;8(2):124-136. doi: $10.2307 / 3583186$

5. Brubaker L, Handa VL, Bradley CS, et al. Sexual function 6 months after first delivery. Obstet Gynaecol. 2008;111(5):1040-1044. doi:10.1097/AOG.0b013e318169cdee

6. Owonikoko KM, Adeoye AG, Tijani AM, Adeniji AO. Determinants of resumption of vaginal intercourse in puerperium period in Ogbomoso: consideration for early use of contraceptives. Int J Reprod Contracept Obstet Gynecol. 2014;3(4):1061-1066.

7. Tesfay F, Mesfin E, Gedefaw A. Resumption of postpartum sexual intercourse and use of modern contraceptive among in-union women in Addis Ababa: cross sectional study. Ethiop J Health Dev. 2018;10(1):13.

8. Borda MR, Winfrey W, McKaig C. Return to sexual activity and modern family planning use in the extended postpartum period: an analysis of findings from seventeen countries. Afr J Reprod Health. 2010;14:72-79.

9. Rossier C, Hellen J. Family planning during postpartum period in Ouagadougou, Burkina Faso. Population association of America annual meeting. New Orleans; 2013. Available from: https://paa2013. princeton.edu/papers/131993. Accessed August 6, 2020. 
10. Ndugwa RP, Cleland J, Madise NJ, Fotso J-C, Zulu EM. Menstrual pattern, sexual behaviors, and contraceptive use among postpartum women in nairobi urban slums. J Urban Health. 2011;88(Suppl. 2). doi:10.1007\%2Fs11524-010-9452-6

11. Wamala R, Kabagenyi A, Kasasa S. Predictors of time-tocontraceptive use from resumption of sexual intercourse after birth among women in Uganda. Int J Popul Res. 2017;2017. doi:10.1155/ $2017 / 3875452$

12. Vu LTH, Oh J, Bui Q-T-T, Le AT-K. Use of modern contraceptives among married women in Vietnam: a multilevel analysis using the multiple indicator cluster survey (2011) and the Vietnam population and housing census (2009). Glob Health Action. 2016;9(1):29574. doi: $10.3402 \% 2 F$ gha.v9.29574

13. Andi JR, Wamala R, Ocaya B, Kabagenyi A. Modern contraceptive use among women in Uganda: analysis of trend and patterns (1995-2011). Afr Pop Stud. 2014;28(2):1009-1021. doi:10.11564\%2F28$0-553$

14. Islam AZ, Mondal MNI, Khatun ML, et al. Prevalence and determinants of contraceptive use among employed and unemployed women in Bangladesh. Int J MCH AIDS. 2016;5(2):92. doi:10.21106/ijma.83

15. Stephenson R, Baschieri A, Clements S, Hennink M, Madise N. Contextual influences on modern contraceptive use in sub Saharan Africa. Am J Public Health. 2007;97(7):1233-1240.

16. Lutalo T, Kigozi G, Kimeraetal E. A randomized community trial of enhanced family planning outreach in Rakai, Uganda. Stud Fam Plann. 2010;41(1):55-60. doi:10.1111/j.1728-4465.2010.00224.x

17. Igbodekwe FC, Oladimeji O, Oladimeji KE, Adeoye IA, Akpa OM, Lawson L. Utilisation of modern contraceptive among women of childbearing age in resource constraint setting: evidence from 2008 national demographic and health survey in Nigeria. $J$ Health Sci. 2014;4(3):72-78.

18. Neal SE, Chandra-Mouli V, Chou D. Adolescent first births in East Africa: disaggregating characteristics, trends and determinants adolescent health, Reprod Health. 2015;12:13. doi:10.1186/1742-4755$12-13$

19. Osmani AK, Reyer JA, Osmani AR, Hamajima N. Factors influencing contraceptive use among women in Afghanistan: secondary analysis of Afghanistan health survey 2012. Nagoya J Med Sci. 2015;77(4):551.

20. Javed Z, Ahmad M, Munir MR, Saqib M. Exploring the determinants of contraceptive use among married women in Sindh, Pakistan. Health Sci Res. 2014;1(3):25-29.

21. Family Health Initiative. Expanding contraceptive use in urban uttar pradesh: family planning: effect of data driven strategies. Policy Brief. 2010.
22. Nyarko SH. Prevalence and correlates of contraceptive use among female adolescents in Ghana. BMC Womens Health. 2015;15(1):60. doi:10.1186/s12905-015-0221-2

23. Gyimah SO, Adjei JK, Takyi BK. Religion, contraception, and method choice of married women in Ghana. $J$ Relig Spiritual Aging. 2012;51(4):1359-1374. doi:10.1007/s10943-011-9478-4

24. Kayembe PK, Fatuma AB, Mapatano MA, Mambu T. Prevalence and determinants of the use of modern contraceptive methods in Kinshasa, Democratic Republic of Congo. Contraception. 2006;74 (5):400-406. doi:10.1016/j.contraception.2006.06.006

25. Central Statistical Agency (CSA) [Ethiopia] and ICF. Ethiopia Demographic and Health Survey 2016. Addis Ababa, Ethiopia, and Rockville, Maryland, USA: CSA and ICF, 2016. Available from: https://dhsprogram.com/pubs/pdf/FR328/FR328.pdf. Accessed August 6, 2020.

26. Atukunda EC, Mugyenyi GR, Obua C, et al. Provision of family planning vouchers and early initiation of postpartum contraceptive use among women living with HIV in southwestern Uganda: a randomized controlled trial. PLoS Med. 2019;3. doi:10.1371/journal.pmed.1002832

27. Fagbamigbe AF, Adebowale AS, MorhasonBello IO. Survival analysis of time to uptake of modern contraceptives among sexually active women of reproductive age in Nigeria. BMJ Open Diabetes Res Care. 2015;5:e008371. doi:10.1136\%2Fbmjopen-2015-008371

28. Kravdal O. A search for aggregate-level effects of education on fertility, using data from Zimbabwe. Demogr Res. 2000;3: doi:10.4054/DemRes.2000.3.3

29. Al Riyami A, Afifi M, Mabry RM. Women'sautonomy, education and employment in Oman and their influence on contraceptive use. ReproductiveHealthMatters. 2004;12(23):144-154. doi:10.1016/ S0968-8080(04)23113-5

30. Huang Y, Merkatz R, Kang J, et al. Postpartum unintended pregnancy and contraception practice among rural-to urban migrant women in Shanghai. Contraception. 2012;86(6):731-738. doi:10.1016/j.

31. Tran NT, Gaffield ME, Seuc A, et al. Effectiveness of a package of postpartum family planning interventions on the uptake of contraceptive methods until twelve months postpartum in Burkina Faso and the Democratic Republic of Congo: the YAM DAABO study protocol. BMC Health Serv Res. 2018;18(1):1. doi:10.1186/s12913018-3199-2

32. Whaley N. Contraception in the postpartum period: immediate options for long-acting success. SAGE J. 2015;11:97-99. doi: $10.2217 /$ whe. 14.78

\section{Publish your work in this journal}

The International Journal of Women's Health is an international, peerreviewed open-access journal publishing original research, reports, editorials, reviews and commentaries on all aspects of women's healthcare including gynecology, obstetrics, and breast cancer. The manuscript management system is completely online and includes a very quick and fair peer-review system, which is all easy to use. Visit http://www.dovepress.com/testimonials.php to read real quotes from published authors. 